\title{
Tres Biografías
}

\author{
por Alberto Tauro
}

LUNA PIZARRO, Francisco Xavier de (Arequipa 1780 - Lima 1855), clérigo y político. Fué presidente del primer Congreso Constituyente (1822); redactó las bases de la constitución aprobada en 1823, y decidió el acentuado liberalismo de las cartas políticas de 1828 y 1834; en los últimos años de su vida se dedicó a su ministerio, y los caudillos a quienes había combatido favorecieron su consagración como Arzobispo de Lima (1845-1855).

Francisco Xavier de Luna Pizarro nació en Arequipa, el 3 de diciembre de 1780. Fué el segundo hijo del matrimonio efectuado el 29 de abril de 1779, entre Juan Bautista de Luna Pizarro - Teniente Coronel de milicias, oriundo de Granada-dy Cipriana Pacheco Ärauz. Desde su cuna fué destinado a la carrera eclesiástica, en armonía con normas muy extendidas en aquella época, o tal vez para franquearle la protección de su tío y padrino de bautizo, el canónigo Francisco Xavier Pacheco. A los once años ingresó al Seminario Conciliar de San Jerónimo, cuyos estudios se desenvolvían entonces bajo la renovadora dirección del obispo Pedro José Cháves de la Rosa. Y se cuenta que, vi sitando éste los claustros, sorprendió en cierta oportunidad a los alumnos en desordenada algazara, debido a la ausencia del profesor de latín; tomó a su cargo la clase, y con pausada severidad inició el interrogatorio que le permitiría adelantar sus explicaciones; pero el respeto que imponía la austera personalidad del prelado, la sorpresa o la falta de aplicación, inspiraron a aquellos sólo el silencio o un tímido balbúceo, y uno a uno fueron amonestados. Tocó al fin su turno a Francisco Xavier de Luna Pizarro, quien meditaba su contestación con la mirada en el vacío cuando el dómine le dirigió su adusta sentencia; y como dicho alumno mascullara oscuras expresiones de rebeldía, fué apre- 
miado para que las repitiese; dijo entonces al obispo que, si no temiera incurrir en la fáma de atrevido, podría formularle alguna pregunta que también lo hiciera cavilar; paternalmente autorizólo Cháves de la Rosa a enunciar la pregunta en cuestión, que se habría enderezado a inquirir cuántas" veces se dirige el sacerdote a los feligreses durante la misa para invocar su comunión con Dios; y, según lo había esperado el mozuelo, vaciló el ilustre prelado, elevó la mirada hacia el espacio, e hilvanaba quizá la respuesta cuando fué cortado por una advertencia pertinente a esa actitud meditativa que antes le pareció indicadora de ignorancia. Como por encanto desapareció de su rostro el ceño que sobrecogiera el ánimo de los estudiantes $\mathrm{y}$, ganado por el ingenio de Luna Pizarro, otorgóle desde entonces su afecto y su favor (1).

Allí, en el Seminario Conciliar de San Jerónimo, recibió la primera tonsura, el 16 de diciembre de 1791; sucesivamente estudió Latinidad y Retórica, Filosofía, Sagrada Teología y Jurisprudencia Civil; y demostró tan altas dotes que el obispo Pedro José Cháves de la Rosa decidió enriquecer su educación con la enseñanza de las matemáticas. Al terminar, en 1798, viajó a Cuzco, en cuya universidad optó la licenciatura en Leyes y. Sagrados Cánones, el 26 de junio, después de haber rendido examen ante el claustro pleho; y el 5 de julio, la licenciatura en Sagrada Teología. A pedimento suyo fué autorizado, el 12 de julio, para hacer la práctica de Derecho Civil y Derecho Canónico, en Arequipa, y bajo la tutela del abogado que eligiese. Volvió entonces a su ciudad natal. Merced a la protección del obispo, el 3 de agosto de aquel año fué incorporado en el Seminario Conciliar de San Jerónimo aa la cátedra de Filosofía ("que abrasaba la Historia de la Filosofía, Lógica, Metafísica, Física general y particular, y Etica"); y después de conferirle las órdenes menores, el 13 de abril de 1799, el propio Cháves de la Rosa le ofreció un cargo entre sus familiares.

Francisco Xavier de Luna Pizarro atendía simultáneamente a la práctica forense, en el estudio de Evaristo Gómez Sánchez, testigo excepcional "de su fina habilidad, de su constancia y aplicación a los estudios, de su pericia en aquellas ciencias que ha acreditado, ya como discípulo, ya como maestro, en las muchas funciones públicas literarias en sus aulas, y en las de los regulares en que como replicante se ha presentado, en la de oposición a la canongía magistral [el 7 de agos-

(1).-Cf. ¿Al rincón! ¡Quita calzón! por Ricardo Palma, en sus Tradiciones Peruanas. 
to de 1799] y últimamente en la presidencia de conclusiones generales de todos los ramos de la filosofía moderna y la moral, cuya cátedra obtuvo y desempeñó con copia de discípulos aprovechados, y todo esto en la corta edad que manifiesta, aunque de anciano es la,conducta" (2). A mediados de 1801 viajó nuevamente a Cuzco; y después de lograr que se le dispensara el estricto cumplimiento de los cuatro años de práctica, rindió las pruebas de estilo el 28 de setiembre, y formuló ante la Real Audiencia el juramento requerido para ejercer la abogacía. De vuelta en Arequipa, envió poder a Francisco Flores, para que solicitase a la Real Audiencia de Lima su incorporación y la respectiva matrícula en el Colegio de Abogados, las cuales fueron dispuestas por acuerdo del 25 de enero de 1802. Continuó en el Seminario la enseñanza de Filosofía Moral, e inició la de Matemáticas puras, y por ello se le recuerda como "el primero que enseñó públicamente en Arequipa las ciencias exactas, y el que estimuló a los jóvenes a que se dedicasen a ellas, para cuyo fin trabajó un Discurso probando la necesidad del estudio de la Geometría y su útil y feliz aplicación a las demás fácultades" (3); y regentó dichas asignaturas hasta agosto de 1804, pues, como familiar del obispo Cháves de la Rosa, hubo de acompañarlo en su viaje a Lima, cuando renunció su prelacía. Pero, como ya había cumplido su deber magisterial, recibió las órdenes mayores, y el 13 de agosto de 1806 dispuso el arzobispo Bartolomé María de las Heras que las respectivas licencias fuesen extensivas a toda la arquidiócesis.

Desde el 5 de setiembre de 1805, el Sumo Pontífice había resuelto acoger la petición presentada por el lobispol Pedro fosé Cháves de la Rosa, para que se declarase disuelto el vínculo que lo ligaba a su diócesis; y mediaba el año 1806 cuando la noticia llegó a Lima. Inmediatamente la comunicó el prelado renunciante al vicario general del obispado de Arequipa, doctor Juan José Manrique; y, así como los beneficios que hasta entonces había percibido, declinó también la compañía de sus familiares. Por eso retornó a la ciudad mistiana Francisco Xavier de Luna Pizarro, donde inmediatamente ocupó la prosecretaría

(2).-Cf. el expediente de grado que se conserva en el archivo de la antigua Audiencia de Lima, actualmente bajo la custodia de la Corte Suprema. Copia certificada del mismo, seguida de diligencia efectuada en 1808 para obtener la devolución del título original, se conserva en el archivo de la familia Ortiz de Zevallos y Paz Soldán.

(3).-Cf. Relación de los méritos y exercicios literarios del presbítero Licdo. D. Francisco Xavier de Luna Pizarro .... Sevilla, 1809. 
del obispado; y, desde el 20 de noviembre de 1807, los cargos de vicerector y prefecto de estudios del Seminario Conciliar de San Jerónimo, en cuyas aulas tuvo como alumnos al poeta Mariano Melgar y a Francisco de Paula González Vigil. Allí siguió puntualmente las reglas establecidas por el obispo al reformar la institución; formó un inventario de sus bienes; trasladó y arregló las bibliotecas que fueran de Cháves de la Rosa y de los Jesuitas.

El 2 de junio de 1808 destinólo el virrey Abascal al curato de San Agustín de Torata, cuyo anterior titular había recaudado anticipadamente las primicias que constituían su renta, motivando la queja entablada por Luna Pizarro ante el vicario general de la diócesis. Pero sólo desempeñó aquel ministerio durante unos meses; pues, en calidad de familiar del obispo Cháves de la Rosa, fué requerido para acompañarlo y prestarle asistencia en la conclusión de la memoria que acerca de su gobierno apostólico debía presentar; y en octubre del mismo año obtuvo licencia para trasladarse a Lima. Terminada aquella tarea, y hallándose en la rada del Callao el navio San Fulgencio (marzo de 1809), ofrecióle el prelado la oportunidad de viajar a España, y Francisco Xavier de Luna Pizarro solicitó licencia para acompañarlo. Alegó que esperaba frecuentar "alguna de las universidades célebres de la Europa, para aprender allí las lenguás hebrea, griega y arábiga ... cuyo conocimiento no se puede adquirir en este reino por no haber cátedra de ellas en sus Universidades, ni peritos que puedan dedicarse a su enseñanza"; y el obispo informó que su antiquel discípuloera el único sacerdote que se había mostrado dispuesto a navegar en su compañía, y auxiliarlo, porque así le agradecía el haberle "costeado la carrera de estudios y grados desde la edad de diez años en que, huérfario y sin otros auxilios, entró en el Colegio de Sán Jerónimo" (4):

En la península, el presbítero arequipeño observó atentamente la crisis política y social, acumulando una experiencia que sería decisiva en el curso posterior de su vida. Asistió a la resistencia que el pueblo opuso a la ocupación napoleónica, y así afianzó su confianza en la soberanía popular; designado capellán del Presidente del Consejo de In-

(4).-En el archivo de la familia Ortiz de Zevallos y Paz Soldán se conserva copia certificada del expediente iniciado por el obispo Pedro José Cháves de la Rosa, para obtener licencia, con objeto de viajar a España en compañía de su familiar. 
dias (5), presenció, en Cádiz, las sesiones de las Cortes; y, al mismo tiempo que siguió sus procedimientos y los conciertos particulares de los diputados, guardó imborrable memoria de los debates suscitados por la libertad de imprenta y los principios constitucionales de la monarquía española. De otra parte, atendía el obispo de Sigüenza a "las recomendables y singulares prendas de talento y probidad" que caracterizaban al presbítero arequipeño, para autorizarlo a ejercer su ministerio; Y, para aprovechar "sus luces", resolvió nombrarlo examinador sinodal del obispado (26 de noviembre de 1811). Bien pudo imaginar entonces la posibilidad de un cambio político en el Perú, y el especial influjo que en sus alcances podría tener su voluntad, cuando embarcó en la goleta Hermosa Mextcana, el 22 de diciembre de 1811, con destino al Callao. Arribó el 16 de abril de 1812, cuando la opinión del país se hallaba agitada por las elecciones en virtud de las cuales se designaría por primera vez a los diputados a Cortes.

Francisco Xavier de Luna Pizarro volvió para ocupar en el coro metropolitano de Lima la dignidad de medio racionero, que el 6 de junio de 1811 se le había otorgado, por intercesión del ilustre Pedro José Cháves de la Rosa, elevado a la jerarquía de Patriarca de las Indias: y, por fallecimiento del titular, fué promovido a la dignidad de racionero el 23 de octubre de 1816. Pero su celo y su clarividencia le atrajeron otras responsabilidades y distinciones: pues, a poco de asumir la posesión de su canongía, le fué confiada la secrètaría del cabildo eclesiástico, la

(5).-La (-anscripción original del decreto respectivo se conserva en el archivo de la familia Ortiz de Zevallos y Paz Soldán. Su texto es el siguiente:

" $D$ n. Francisco Requena, Mariscal de Campo de los Rs. Exércitos, del Consejo de S. M. y su Ministro Decano en el Consejo y Cámara de Indias: Hallándose vacante la plaza de Capellán del mismo Consejo por no haberse presentado a servirla el que la obtenía quando el referido tribunal residía en Madrid, y conviniendo el que haya persona que desempeñe sus funciones; en virtud de las facultades que como tal Decano de él me corresponden, nombro para que la sirva interinamente al Lizdo. Dn. Franco. Xavier de Luna y Pizarro, Presvítero, Cura de la Doctrina de Torata, en el obispado de Arequipa, opositor a Prebendas de Oficio, que con la correspondiente licencia del Virrey del Perú, y Governador de aquel Obispado, ha venido a España en compañía del Revdo. Obispo que fué de Arequipa Dn. Pedro Josef Chabes de la Rosa, y reside en esta ciudad; con la dotación por ahora de quatrocientos ducados anuales, que se le satisfarán del fondo de Penas de Cámara, y empezará a disfrutar desde el día que principie a celebrar misa en el Oratorio del mismo Consejo a la hora que se le señale, cuyo destino deberá exercer durante el tiempo qe. resida y mientras no se le proporcione su traslación a América. Cádiz, diez y siete de enero de mil ochocientos y once". 
cual desempeñó puntualmente hasta febrero de 1822; por acuerdo de las Cortes (agosto de 1813) fué nombrado vocal de la Junta Censoria de Lima y, coherentemente, se le encargaron en este arzobispado las delicadas tareas de examinador sinodal. Por añadidura, la Junta Electoral de Arequipa, en sesión efectuada el 5 de octubre de 1813, lo eligió dipulado suplente por aquella provincia, ante las Cortes reunidas en Cádiz; $y$, aunque no llegó a incorporarse a esa histórica asamblea, el honor que se le había conferido le dió oportunidad para revelar sus conceptos sobre la sujeción de la labor parlamentaria a las instrucciones de los comitentes, y su inspiración en el "amor a la justicia y celo por el bien del pueblo".

Para cautelar la ortodoxia doctrinal, Francisco Xavier de Luna Pizarro necesitaba informarse debidamente, y solicitó licencia para leer libros prohibidos. Le fué acordada -n Madrid, a 30 de marzo de 1816- para "adquirir, tener y leer libros prohibidos por el Santo Oficio, excepto los de Nicolás Maquiavelo y demás que tratan exprofeso contra nuestra sagrada religión, y de obscenidades, teniendo dichos libros con la debida custodia y reserva para que no pueda leerlos otra persona, y con la calidad de manifestar esta liceñcia antes de su uso.. al Tribunal de Inquisición en cuyo distrito residiere" (6). Pero, recibida en Lima el 7 de febrero de 1817, este Tribunal suspendió los efectos de dicha licencia; a mérito de "justos reparos", consultó al Inquisidor General sobre la conveniencia de no darle curso; y así quedó proveído el 14 de octubre de 1817. No obstante, fué simultáneamente promovido a la dignidad delracionero; y el 24 de mayo de 1818 se incorporó al Colegio de Abogados.

En marzo de 1819 fué solicitado para desempeñar el rectorado del Colegio de Medicina de San Fernando, convertido en la prisión donde el bachiller Santiago Távara purgaba la imprudencia que cometiera al permanecer durante cuatro meses a bordo de un barco inglés, y en cuyas aulas fermentaba el racionalismo grato al científico y al humanista y que sólo es posible bajo el aura protectora de la libertad y la tolerancia. Y cuando la Junta de Catedráticos -integrada por los doctores Hipólito Unánue, Miguel Tafur, José Gregorio Paredes y José Pezetimpetró del virrey Pezuela el nombramiento respectivo, apuntó que había juzgado "necesario elegir una persona en quien $a$ las virtudes sacerdotales se unan las luces, la integridad y respeto para contener en sus deberes a la juventud"; y que, debido a las mermas sufridas por las

(6).-Cf. Anales de la Inquisición de Lima, por Ricardo Palma. 
rentas del Colegio, sus miembros se habían dirigido a persona que prefiriese "el amor al bien sobre las utilidades pecuniarias", y habian logrado la aceptación de Francisco Xavier de Luna Pizarro. La voluntad del virrey hubo de inclinarse ante los razonamientos de tal instancia, y el 22 de abril fué nombrado el presbítero arequipeño para ocupar el honroso cargo. En armonía con las disposiciones reglamentarias, optó entonces los grados de licenciado y doctor en la Facultad de Teología de la Universidad Mayor de San Marcos ( 9 de mayo de 1819). Por exigencia de sus funciones debió pronunciar, al año siguiente, una arenga laudatoria de Fernando VII y la monarquía española, durante la conmemoración del natalicio de dicho monarca ( 30 de mayo), pero es fácil advertir que en ella alentaron las esperanzas que a la sazón hacía concebir el movimiento constitucional, que en España había impuesto ( 9 de marzo de 1820) el reconocimiento de la Constitución de Cádiz. Y al cabo de ejercer el rectorado durante cuatro años, pudo ufanarse de haber vencido en el Colegio las agitadas mareas de la guerra emancipadora, manteniendo la regularidad de las labores académicas en tanto que otros planteles habian cerrado sus paertas, y aún cancelando las deudas dejadas por sus antecesores.

En verdad, era un republicano liberal. Y cuando la expedición libertadora arribó a costas peruanas, hizo llegar a sus dirigentes los informes y las reflexiones que podían coadyuvar al desenvolvimiento de su acción. Muy importantes, numerosas y directas debieron ser sus noticias, pues el 28 de setiembre concurrió a las discusiones habidas en casa del general José de la Sernar conl hotivo de un proyecto de defensa que Gaspar Rico y Angulo presentara al propio virrey; y es obvio suponer que su espectable posición y su personalidad, tan austera como discreta, movieran a consultar reiteradamente su opinión acerca de la grave coyuntura. Para comunicar tales noticias empleó muy ingeniosas vías, combinándolas prudencialmente para evitar sospechas e interferencias; y se refiere que varios días se sirvió de un pretendido vendedor de ollas de barro, a quien su mayordomo devolvía con especiosos pretextos la adquirida en la víspera, que bajo un doble fondo ocultaba la -misiva destinada al cuartel patriota (7). Por tanto fué uno de los artífices de la proclamación de la independencia. Y así parecen haberlo reconocido: ya el Arzobispo Bartolomé María de las Heras, cuando lo de-

(7).-Cf. Con días y ollas venceremos, por Ricardo Palma, en sus Tradiciones Peruanas. 
signó (28 de agosto de 1821) para integrar - con el deán Francisco Xavier Echagüe y fray Cecilio Tagle- la Junta de Purificación, ante la cual debían efectuar los curas una información acerca de su conducta política; ya, el Ministro de Gobierno, Bernardo Monteagudo, cuando lo eligió (15 de enero de 1822) para representar al poder ejecutivo en la comisión que elaboraría el proyecto reglamentario de las elecciones para diputados a Congreso, y el proyecto de Constitución del Estado que aquel debía discutir. Al mismo tiempo, contribuyó desde el rectorado del Colegio de Medicina de San Fernando al afianzamiento de la conciencia cívi$\mathrm{ca}$, mediante las solemnes ceremonias en las cuales profesores y alumnos juraron adhesión y lealtad a la independencia del país (30 de julio de 1821), al Estatuto Provisorio dictado por el Protector José de San Martín (18 de octubre de 1821), a la soberanía nacional representada en el Congreso Constituyente ( 26 de setiembre de 1822), a las bases de la Constitución Política de la República (23 de diciembre de 1822). $y$ al Prèsidente que el Congreso Constituyente hubo de reconocer por imperativo reclamo del ejército ( 19 de marzo de 1823).

Aquella firmeza de sus convicciones liberales, convirtió a Francisco Xavier de Luna Pizarro en un activo modelador de las instituciones republicanas. Y claramente lo demostró su actitud en los debates de la Sociedad Patriótica, creada para discutir acerca del régimen de gobierno conveniente al Perú. La primera sesión pública ( $1^{9}$ de marzo de 1822), presidida por el ministro Bernardo Monteagudo, inicióse con una disertación monarquista del celérigoljosé Ignacio Moreno, que inmediatamente fué juzgada por el presbítero Mariano José de Arce como una tardía expresión del absolutismo; y como se hiciera ostensible el desagrado que esta reacción causó al ministro, sostuvo Luna Pizarro que se abstenía de refutar las ideas vertidas por Moreno, pues era menester que previamente se reconociese a los miembros de la Sociedad Patriótica el derecho de oponerse a las ideas expuestas en su seno y se les Sarantizase que no habrian de sufrir por ellas el menor daño; sostuvo también que toda discusión sobre la forma de gobierno conveniente al Perú debía ser tratada únicamente por el Congreso, cuya reunión había anunciado el Protector, y en el cual estarían amparadas las opiniones de los representantes por la inviolabilidad que les reconocía la ley; y finalmente sostuvo que, lejos de limitarse la discusión a un esclarecimiento académico, debía invitarse a los escritores para que escribiesen acerca del tema, pues así se conocería el sentimiento y la voluntad de los pueblos. Justa, pero inesperada, tal actitud cernió el desconcier- 
to sobre el futuro de la flamante institución, y motivó el decreto (5 de marzo de 1822) por el cual se declaró que los miembros de la Sociedad Patriótica no serían "responsables por las opiniones que en ella sostuvieran en materias especulativas, con el celo y candor propios del que busca la verdad". Pero al mismo tiempo solicitó el gobierno la amistosa intercesión de Hipólito Unánue, para evitar que el régimen grato a sus designios sufriese los influyentes embates de Luna Pizarro, y éste se abstuvo de hacer la prometida refutación.

A poco, fué elegido diputado por Arequipa, al Congreso Constituyente de 1822. En él aplicó brillantemente la experiencia adquirida al observar el funcionamiento de las Cortes de Cádiz, y, aunque no se prodigó en los debates, su actividad se multiplicó en los conciliábulos que prepararon las decisiones graves. Impresiones recogidas de sus contemporáneos, hacen saber que "su figura enjuta y raquítica formaba contraste con sus ojos ivivos, centellantes, que arrojaban fuego y electrizaban al improvisar un discurso en la tribuna, o sostener una discusión"; y que "a estas dotes reunía maneras suaves y atractivas y cierta dulzura de carácter, en su trato familiar, que contrastaba de un modo asombroso con la exaltación que sufría al encontrar oposición" (8). Su reconocida versación lo llevó a la presidencia del Congreso Constituyente durante el primer mes de sesiones -o sea, desde el. 20 de setiembre hasta el 20 de octubre de 1822-; y se cuenta que durante ese período solía pasear su ascéticáfigura por los viejos claustros a los cuales do ban los salones ocupados por las diferentes comisiones, a fin de orientar y estimular sus trabajos, y Mariano José de Arce sugirió irónicamente en alguna oportunidad si Francisco Xavier de Luna Pizarro pensaría que los diputados eran colegiales de San Fernando (9). Su aversión a las formas de despotismo que veía asomar tras el gobierno unipersonal, decidió entonces el nombramiento de la Junta Gubernativa que sucedió al Protector José de San Martín en el ejercicio del poder ejecutivo, pero reduciéndola a una ineficiente dependencia de los acuerdos legislativos. Como sincero republicano, propuso que se expulsase del país a los negociantes ingleses, si se negaban a cubrir la parte que se les había asignado en el cupo de 400,000 pesos que el Congreso Constituyente impuso al comercio limeño, porque debían sus ganancias a la

(8).-Mariano Felipe Paz Soldán: Historia del Perú Independiente.

(9).-Sebastián Lorente: Historia del Perú desde la proclamación de la Independencia (Lima, 1876). Cf. p. 123. 
protección del estado y nada podía exonerarlos de contribuir a su sostenimiento. Y, sobre todo, trazó las Bases de la Constitución, que definieron el carácter liberal del nuevo régimen.

De pronto cernióse la sombra ante el horizonte de la república, porque las derrotas sufridas en la primera expedición a "intermedios" restaron considerables fuerzas al ejército patriota. Se resolvió acreditar ante el gobierno de Chile un ministro plenipotenciario, con el objeto de gestionar la cooperación militar de ese país, y el presbítero Francisco Xavier de Luna Pizarro declinó las proposiciones que se le hicieron, pues el fracaso militar era atribuido a la-imprevisión de la Junta Gubernativa, y contra ella trabajaba activamente el Coronel José Mariano de la Riva Agüero y Sánchez Boquete. Consideró necesario afianzar la posición política de la Junta, y oponer su influencia personal a las desbordantes pretensiones del empecinado revolucionario. Pero el gesto fué insuficiente y tardío. El ejército amotinado en sus acantonamientos del fundo Balconcillo, impuso al Congreso Constituyente el retiro de la Junta Gubernativa y la elección de Riva Agüero como Presidente de la República.

Leal a su posición doctrinaria, Luna Pizarro combatió duramente ambas decisiones, porque la exigencia del ejército implicaba el descorocimiento de la soberanía popular, y la obediencia del Congreso daba apariencias legales a la imposición de la fuerza. Previno contra las tiranías que suelen asomar en las insurgencias militares, contra el estímulo que obtendría la ámbición dè Bolivâar a contemplar la división interna del Perú, y contra el peligro que la rebeldía contra la autoridad legítima cernía sobre la libertad. Apelando al testimonio de los doctores José Gregorio Paredes y José Pezet, pretextó un quebranto de salud y solicitó del Congreso Constituyente ( 8 y 11 de marzo de 1823). del Ministro de Gobierno -en lo tocante al rectorado del Colegio de Medicina- y del Gobernador Eclesiástico del Arzobispado las licencias que le permitieran acogerse a los beneficios de un clima "análogo a su constitución física". Ante el notario Ignacio Ayllón Salazar, otorgó poder general a José Gregorio Paredes (12 de marzo), para que atendiese sus intereses según las instrucciones que le dejaba (10). Y emprendió

(10).-Según consta en el registro de escrituras públicas del notario don Ignacio Ayllón Salazar - que se conserva en el Archivo Nacional-, el poder otorgado por Francisco Xavier de Luna Pizarro dice:

"En Lima, corte de la República del Perú, a doce de Marzo de mil ochocientos veinte y tres, año segundo de ella; por ante mí el Escno. y tgos. el 
viaje a Chile, para no entablar relación con un gobierno cuyo origen contrariaba sus opiniones sobre la naturaleza y la formación del poder público.

Aunque confiara en la eficacia de las instituciones republicanas, la alternativa que lo impulsaba a retirarse del país le infundía honda angustia. Durante el viaje, con la mirada vagorosa, debieron asediar su pensamiento los principios doctrinarios que lo informaban, las imágenes de la realidad turbulenta, las esperanzas siempre renovadas. A su lado, con la lealtad y la admiración incubadas durante sus estudios en el Colegio de Medicina, buscaría vitales enseñanzas Melchor José

Sr. D. D. Xavier Luna Pizarro, Prevendado de esta Sta. Yglesia Metropolitana y Diputado propietario de la provincia de Arequipa en el Soberano Congreso Constituyente del Perú, a el qual doy fe conosco, y hallándose de próxima partida a la República de Chile a restablecer su salud otorgó por el tenor de la presente que daba, y dió su poder cumplido, el q. pr. dro. se requiere y es necesario al Sr. D. D. José Gregorio Paredes, Catedrático de Prima de Matemáticas en esta Universidad de Sn. Marcos, Cosmógrafo Mayor de la jurisdicn. de esta República y Diputado propietario del Departamento de Lima en el mismo Soberano Congreso, en primer lugar, en segundo al Sr. D. D. Buenaventura Aranzaens, Juez de dro. de esta 'Corte, y en tercero al D. D. Pedro Antonio de la Torre y Luna, para q. 'cada uno en el orden de su nominación a nombre del Sr. otorgte. y representando su propia persona recaude y cobre judicialmente o extrajudicialmte, de todo individuo que sea su deudor, Tesorerías del Estado y otras corporaciones, y mesa capitular las cantidades de ps., frutos y efectos q. se le están debiendo hasta el día de hoy y debieren eng adelantel de la rta. de/su Prebenda, reditos de los prales. de las capellanías que goza, herencias, legados, donaciones, restituciones, escrituras de obligación, vales, libranzas, conocimtos, cuentas de libros, consignaciones, partidas de Registro, o por otra causa y razón que sea; ajustando y liquidando cuentas con sus deudores y acreedores, las quales aprobarán y adicionarán según sus conocimientos y documentos con que se instruyan, o nombrando en caso preciso contadores expertos q. las ajusten y liquiden, y con precedente aprobación cobrarán y pagarán su resultado $=$ Para q. puedan transar y cortar las partidas, créditos y acciones dudosas y los pleytos por compromisos, nombrando jueces, juris, arbitros, arbitradores, amigables componedores y terceros en discordia, obligandolo a q. estará y pasará por las transaciones q. hagan, laudos y sentencias q. se pronuncien dentro del término q. señalen bajo las penas, juramtos., clasulas y condiciones q. pactaren. = Para q. puedan vender qualesqa. de mis bienes, muebles y esclavos en el mejor precio q. se proporcione, dándose por entregados del dinero de su valor en forma legal, desistiéndolo de la propiedad que transferirán en el comprador o compradores, y obligándolo al saneamto. de ella: En conseqa. de todo otorgarán por ante qualquier Escno. de fe publica recibos, cartas de pago, chancelaciones, finiquitos, lastos, transaciones, com- 
Ramos, que volvía a su nativa ciudad de Santiago, deslumbrado ante las perspectivas de sus dieciocho años. $Y$, ya en Chile, siguió la dispula entre el Congreso y el Presidente Riva Agüero. Decidida la exoneración de éste, pareció dispuesto a reincorporarse al seno de la representación nacional, con el ánimo de intervenir en la elaboración de la carta constitucional; pero hubo de diferir tal propósito, primero por el mal estado de su salud, luego por haber llegado a su conocimiento el inmediato término de la Constitución, $\mathrm{y}$, finalmente, por haberse conferido a Bolívar la dictadura. Permaneció en Chile. Frecuentó la tertulia

promisos, ventas y quantos instrumtos, y resguardos se le pidan, con aquellas clausulas q. hagan la mayor seguridad; y siendo necesario contender judicialmte. sobre los cobros y en la defensa de los pleytos activos y pasivos q. le puedan ocurrir, se presentarán ante las justicias superiores e inferiores de ambos fueros de esta Corte con los papeles y documtos. respectivos, pidiendo reconocimtos., juramtos., mandamtos., requerimtos., execuciones, embargos, pregones, ventas, trances y remates de Bienes, y executen cuantos actos y diligencias judiciales y extrajudiciales convengan hasta $q$. hagan efectivos los cobros, y los pleytos se fenescan y acaber, por los trámites de dro: Para todo lo qual da y confiere a los referidos SS. el D. D. José Gregorio Paredes, D. D. Buenaventura Aranzaens y D. D. Pedro Antonio de la Torre y Luna en primero, segundo y tercero lugar el más amplio y eficaz Poder q. necesiten por su orden con libre y gral admon. sin ninguna limitacion en quanto a lo referido y sus incidencias, con reservación de costas en forma y facultad espresa de q. lo puedan substituir en el todo o parte y pa. donde convenga, revoquen unos substitutos, y nombren otros de nuevo, y arreglándose pa. quanto pueda ocurrir sobre sus negociosse intereses a las instrucciones q. les deja y a las cartas órdenes q. les remita; y al cumplimto. y firmeza de quanto executen en virtud de este Poder obliga sus Bienes habidos y por haber y se somete a las justicias que de sus causas deban conocer pa. q. a su observancia lo executen en forma y conforme a dro. renuncia las LL. en su favor y la q. prohibe la gral. renunciación: en cuyo testimonio así lo otorgó y firmó dho. Sr.- D. D. Xavier Luna Pizarro, siendo testigos D. Gabriel Vicente de Acosta, D. Manuel Mesa y D. Mateo Aillón y Escobar. = Xavr. de Luna Pizarro. Ante mí Ignacio Aillon Salazar.

(Nota al margen). "En Lima a primero de Sepre. de mil ochocientos veinte y tres, año segundo de la República del Perú por ante mí el Escno. y testigos el Sr. D. D. José Gregorio Paredes, Diputado propietario en el Soberano Congreso Constituyente del Perú a el qual doy fe conosco, y en voz y a nombre del Sr. D. D. Xavier Luna Pizarro, Diputado en el mismo Soberano Congreso, auste. en la República de Chile, y en virtud de su antecedte. Poder, usando de la facultad de substituir, q. en el le confiere, otorga q. lo substituye y substituyó en el D. D. Pedro Antonio de la Torre y Luna, nombrado en tercero lugar pa. q.me de dicho poder en todas las partes q. contiene; asimismo lo substituyó en el Prodr. d. José Gutiérrez pa.q. entienda 
del ministro Joaquín Campino, y su familiaridad con los personajes del gobierno hizo creer que actuaba a su lado como consejero privado. En marzo de 1824, la Municipalidad de La Serena acordó ofrecerle la Dirección de Estudios del Instituto Departamental, con una dotación anual de 800 pesos, pero declinó aceptarla por haberse informado de no ser propicias a su salud las condiciones del clima. Y en mayo le fué ofrecido el rectorado del Instituto de Chile, pero solicitó las constituciones que regían el establecimiento, y no aceptó el cargo sino después de introducir las reformas de carácter orgánico que le parecieron convenientes.

Al quedar sellada la independencia, en los campos de Ayacucho, el presbítero Francisco Xavier de Luna Pizarro decidió establecerse en su ciudad nativa, para desempeñar la tesorería del coro de la catedral, a la que fué destinado por Bolívar el 29 de marzo de 1825, a méri-

unicamte. en la defensa de los pleytos q. tiene y tuviese el Sr. D. Xavier, y cada uno en su lugar exercerán sus respectivos cargos del mismo modo q. lo hiciera el $\mathrm{Sr}$. su instituyente siendo presente y con la misma relevación de costas y obligación de bienes que tiene hecho en dho. podr. En cuyo testimonio así lo otorgó y firmó siendo testigos D. Gabriel Vicente de Acosta, D. Manuel Mesa y D. José Aillon. José Gregorio Paredes. Ante mí, Ignacio Aillón Salazar.

(Segunda nota al margen). "En Lima a diez y nueve de Dicre. de mil ochocientos veinte y tres: El Sr. D. José Gregorio Paredes revocó la antecedente substitución, pa. q. no corra, valga ni subsista, pr. liberar del cargo al D. D. Pedro Antonio de la Torre, con consideración a sus atenciones y q. pr. ausencia del Sr. otorgante deben pasarel exercicio deD poder al Sr. D. D. Buenaventura Aranzaens nombrado en segundo lugar, y lo firmó, de q. doy fe siendo testigos D. Gabriel Vicente de Acosta, D. Manuel Mesa y José Aillón. José Gregorio Paredes. Ignacio Aillón Salazar".

Pues bien. Aparte de los actos propios de toda administración, consta que el doctor José Gregorio Paredes representó a su poderdante en la liquidación de las dietas que, por resolución de Bolívar, se abonó a los diputados, al clausurarse el Congreso Constituyente. Así aparece de los documentos que a continuación trascribimos, de los originales existentes en el Archivo de la Cámara de Diputados:

19- "Razón de lo que por las dietas señaladas a los SS. Diputados corresponde al D. D. Javier de Luna Pizarro y presenta su apoderado el D. D. José Gregorio Paredes, hallándose el Sr. Luna en el estado de Chile.

Por once días contados del 20 de Sete. de 1822 en qe. se Ha de haber instaló.el Congreso y entró en su seno el interesado, al 30 del mismo mes, a razón de 10 ps. diarios: cientó diez ps. Por noventa y dos días de los tres últimos meses de dho. año: novecientos veinte ps. 
to de una resolución legislativa (11) que excitó su interés en tal nombramiento. Abandonó Santiago de Chile el 16 de agosto; y después de cuatro días de penosa travesía, por caminos fangosos, encontróse en Valparaíso, donde tomó pasaje en la goleta Seis Hermanos. En Arequipa fué incorporado a la Academia Lauretana de Cien-

Por todo el año de 1823 respecto a haber partido pa. Chile en Marzo con licencia del Soberano Congreso q. se le prorrogó en 12 de Eno de 1824 segn. consta del adjunto documto. que se acompaña pa. qe. visto se devuelva: tres mil seiscientos cincuenta ps.

Por el mes de enero de 1824: trescientos diez.ps.

Por diez y siete días del mes de Febr' contados del 1ro a aquel en que se puso el cúmplase al Sobno. Decreto de 10 del mismo mes pr. el cual se resolvió el receso del Congreso: ciento setenta

Suma ps.

5160

Los mismos que integramente se deben al Sr. Luna por sus dietas: respecto a que los últimos pagos que se le hicieron en razón de Prevendado de esta Sta. Ig ${ }^{a}$ son correspondtes. al año eclesiástico cumplido en 31 de Julio de 1822. Lima y Marzo 4 de 1825. José Gregorio Paredes:

29- "El Sr. D. Javier de Luna Pizarro por razón de sus dietas como Diputado del Soberano Congreso Constituyente del Perú, elegido pr. el Departamento de Arequipa.

Por quinientos diez y seis días útiles que le son abonables Ha de haber desde el 20 de Sete. de 1822 que prestó juramento hasta 17 de Febro de 1824 a 10 ps. 5160

Estuvo el Congreso en receso desde el 18 de Febr 9 de 1824 al 10 de Febrr 9 de 1825 en que nada se abona Tampoco se abona al Sr. Luna cosa alguna pr. los veinte y nueve dias en que ha tenido el Congreso sesiones desde el 10 de Febro de 1825 hasta el 10 de marzo del mismo año pr. no haber asistido personalmte. a ellas.

Alcanza, cinco mil ciento sesenta pesos

Lima, Marzo 8 de 1825 - Manuel de Salazar y Vicuña - Franc 9 Agustín Argote - Joaquín de Arrese - J. Modesto Vega. Como apoderado del S. D. D. Javier Luna Pizarro, segn. consta del documto. adjunto, recibí el libramiento respectivo bajo el No 3. José Gregorio Paredes".

(11). - La citada resolución legislativa, aprobada en la sesión del 10 de marzo de 1825, establece: "Que se diga al Libertador que el Congreso mirará con la más grata complacencia la colocación del Dr. Javier Luna Pizarro, su primer Presidente, en alguna de las dignidades vacantes en el Coro de Arequipa, o, en su defecto, en una canongía del mismo coro, y que cuando lugar no haya, se le dé el ascenso que por orden de escala le corresponde en esta Iglesia Metropolitana". 
cias y Artes ( 2 de noviembre de 1825). Y, deponiendo "hasta los menores vestigios de recelo o desconfianza", expresó al Libertador la admiración que le inspiraba el "golpe de trueno" descargado sobre el poder español. Aparentó consagrarse a su ministerio, pero al mismo tiempo comenzó a minar con mucha habilidad las posiciones de la dictadura bolivariana. Durante largos meses incitó al General José de La Mar, para que asumiese la presidencia del Consejo de Gobierno y pusiese su influencia al servicio de la ley; pero éste se mantuvo alejado de Lima y permaneció muy corto tiempo en su alto cargo. Entonces comprendió Luna Pizarro que era menester alterar su procedimiento, e inició una cautelosa aproximación al Libertador. Epistolarmente admitió (28 de setiembre) una paladina concesión a sus propios principios, porque "necesitamos un genio superior que nos enseñe a discernir el bien real y sólido del aparente" y "las sublimes virtudes" desplegadas por Bolívar habían hecho desaparecer "hasta los menores vestigios de recelo - desconfianza, inseparables de todo fiero republicano a la vista de un gran capitán, cuya gloria se teme pueda eclipsar la libertad civil". Pero el halago era sólo un embozo que el "fiero republicano" adoptaba para deslizar sus más íntimas opiniones: "porque no hay otra libertad verdadera que el ejercicio de la virtud o el imperio de la ley", y para coronar su obra debía el "gran capitán" mostrar su desprendimiento a "la envidiosa Europa" y convertirse en "digno émulo de Washington". El halago dió los frutos que no acierta ca negar ni aún la sensibilidad mejor prevenida y no fué calada la pertinaz virtud del republicano. Por eso creyó el Libertador que podía obtener la colaboración del presbítero Francisco Xavier de Luna Pizarro, y otorgarle un lugar entre los más próximos colaboradores de un gobierno que debía presidir el General José de La Mar: "pues -según escribió al General Tomás Heres, desde Potosí, el 27 de octubre de 1825- el ministerio de gobierno requiere un hombre como Luna Pizarro, de talento, crédito y energía, $\alpha$ migo de La Mar y enemigo de Torre Tagle". Así lo expresó también al caudillo liberal, anunciándole su deseo de reformar la constitución para armar de mayores recursos al poder ejecutivo. Asintió el fiero republicano, porque "a las veces debe cubrirse con un velo la libertad", a fin de evitar "la tiranía de algún feliz malvado"; y aunque parecía dolerse ante la posibilidad de que se ausentase el Libertador, apenas ocultaba su gozo al sostener que "el único para la presidencia es el señor General La Mar, adornado de virtudes eminentes que no resplandecen tanto en otros ciudadanos, y de un patriotismo desinteresado; 
que... es el alma del republicanismo en los momentos de constituirse el Estado". De patriotismo desinteresado alardeaba también el presbítero, al pretender que se hallaba "decidido a no salir de la oscuridad"; pero su satisfacción reboza la estudiada sobriedad de las palabras cuando anuncia a Bolívar su elección como diputado departamental por Arequipa y define el Congreso como "templo donde la razón, acorde con la voluntad [popular], pronunciará la ley". Es, como siempre, un fiero republicano. $Y$ en las reuniones preparatorias del Congreso, iniciadas el 29 de marzo de 1826, Francisco Xavier de Luna Pizarro desplegó su capacidad dialéctica para combatir la prórroga de la díctadura y la proyectada adopción de la constitución vitallicia. "Qué malditos diputados ha mandado Arequipal" -opina el Libertador al cabo de una semana, en carta dirigida al General Antonio Gutiérrez de la Fuente, quien a la sazón desempeñaba la prefectura de aquel departamento-: "si fuera posible cambiarlos sería la mejor cosa del mundo". Juzga que Luna Pizarro deseaba "disponer de todo a su antojo". Y en términos coincídentes opina William Tudor - cónsul de Estados Unidos en Lima-, cuando anota que la oposición tiene en él "su jefe y su alma". O cuando expresa la impresión que le ha causado su personalidad: "Es un hombre de talento, de maneras agradables, muy republicano en sus principios, y parece que de sacerdote no tiene más que el hábito" (12).

Acaudillado\$ por Francisco Xavier de Lung Pizarro, los liberales advertían que la guerra se hallaba terminada y la fuerza de las bayonetas no debía ser ya el principal instrumento del gobierno; deseaban ansiosamente la continuación del Libertador en la dirección de los asuntos públieos, pues su experiencia y su influencia eran de suma importancia para el desenvolvimiento de la administración, pero siempre que su autoridad quedase enmarcada por los preceptos constitucionales; estimaban que las alternativas de la política colombiana

(12).-Cf. Correspondencia diplomática de los Estados Unidos concerniente a la independencia de las Naciones Latinoamericanas, seleccionada y arreglada por William R. Manning ... Versión castellana por Pedro Capó Rodriguez. Buenos Aires, Libreria y Editorial La Facultad, 1930-1932. 3 v. en 6.

Si bien es interesante el juicio de William Tudor acerca de Luna Pizarro, debe llamarse la atención hacia los errores biográficos que desliza en la misma carta. Dice: "Fué miembro de las Cortes españolas, en las que fué considerado como ultraliberal; [y] fué en el Perú un patriota tan resuelto, que mientras los españoles dominaron en Arequipa se vió obligado a qusentarse y residir en Chile". 
podían exigir la presencia de Bolívar en su país y, si en tal oportunidad no se encontraba organizado el Perú según los principios liberales, podían derivarse graves peligros y dificultades; creían que los miembros del Consejo de Goblerno eran monarquistas, y tan incapaces para resolver los problemas de la administración que aún el $\mathrm{Li}$ bertador se había visto obligado a anular muchos de sus actos, por lo cual temían que pudiera sobrevenir el desconcierto si ellos quedaban encargados del poder ejecutivo; proyectaban seleccionar un grupo de jóvenes inteligentes, para que estudiasen los procedimientos administrativos y legislativos en Estados Unidos y Europa, y al cabo de cuatro o cinco años aplicasen en las dependencias del Estado los conocimientos adquiridos; reclamaban una acción inmediata para superar el estado ruinoso de la hacienda, cuya dirección debía basarse en un examen minucioso y en la publicidad de los gastos y los ingresos públicos; y esperaban que el Congreso reformase la Constitución, en armonía con las luces de los diputados elegidos por primera vez en todas las provincias del territorio nacional. Pero aquellos objetivos fueron diferidos, cuando la mayoría tachó algunas actas electorales y decidió solicitar que se postergase hasta el año siguiente la convocatoria a Congreso. Y como el Consejo de Gobierno pretendía que se adop- tase en el Perú la constitución que el Libertador había dictado a Bolivia, sancionó diversas medidas para amedrentar y disolver a la oposición liberal. Francisco Xaviet de Luna Pizarro no se doblegó ante los halagos, y no pareció enterarse de que se le había implicado en una presunta conspiración contra la vida de Bolivar. Nombrado Ministro Plenipotenciario en México ( 13 de agosto de 1826), alegó razones de salud para demorar su partida. Acudió luego al Palacio de la Magdalena, con ánimo de moderar los juicios que pudiera merecer su actitud; pero el Libertador se negó a concederle audiencia, y se afirma que privadamente atribuyó la renuencia del caudillo liberal a su intenclón de no aceptar sino la posición que le permitiera mandar a los que mandan. Se le entregó su pasaporte ( 14 de agosto), con la obligación "de no regresar sin previo aviso del gobierno", y nuevamente hubo de salir desterrado a Chlle, donde le fueron franqueadas las páginas de $E l$ Cometa - que a la sazón editaba Melchor José Ramos, alumno del Colegio de la Independencia durante el rectorado del presbítero arequipeño- para publicar noticias y juicios sobre política peruana.

Alejado Bolívar, y derogada la constitución vitalicia por el pronunciamiento de las tropas auxiliares colombianas, Francisco Xavier de 
Luna Pizarro pudo volver al país. William Tudor, -quien lo apreciaba como "el más ilustrado, el más liberal, el más puro de los patriotas peruanos, y el más versado en todas las materias constitucionales" (13)- ofrecióse a enviarle los despachos oficiales, para excitar su inmediato retorno; y para este efecto dispuso el gobierno chileno la partida del bergantín de guerra Aquiles. El 29 de abril de 1827 desembarcó en la rada chalaca, donde fué efusivamente recibido por Manuel Lorenzo de Vidaurre - Presidente de la Corte Suprema y artífice de la reacción antibolivariana- $\mathrm{y}$ otros amigos, que en sus carruajes lo escoltaron hasta Lima. Numeroso pueblo lo esperaba en las afueras de la ciudad. "Batían las banderas, y el sonido de los instrumentos alternaba con los infinitos palmoteos y vivas. Las calles eran cuasi intransitables por el concurso. Los balcones estaban adornados con exquisitas colgaduras y coronados de personas del bello sexo" (14). Luna Pizarro y Vidaurre fueron arrebatados por la muchedumbre, y a pie marcharon hasta el Palacio de Gobierno, donde el general Andrés de Santa Cruz -Presidente de la Junta de Gobierno- ofreció en su honor un "soberbio banquete". Y, el propio Vidaurre, alentado por las afinidades políticas y familiares que lo unían a Luna Pizarro, lo invitó a una comida y a un paseo campestre. A la primera concurrieron los miembros del gobierno y los más notorios exponentes del liberalismo, quienes a la hora de los brindis saludaron "a la libertad de la patria, [así como] al odio a los tiranos y ä la tiranía"; y durānte el segundo, mientras rodaba el coche a través de los polvorientos caminos, una y otra vez incidió Vidaurre en ell problema de la inminenter elección presidencial, en tanto que Luna Pizarro soslayaba el tema con displicencia y dejaba que su fogoso pariente abundase en razones y opiniones acerca de la coyuntura y los hombres del país. $Y$, sin embargo, esta inquisición era innecesaria, pues hacía tiempo que William Tudor anunciara al Secretario de Estado de Estados. Unidos: "La Mar, con quien [Luna Pizarro] sostiene la más estrecha amistad, será, sin duda, elegido para la presidencia, y bajo la dirección de esos dos hombres el Perú puede esperar la prosperidad y la felicidad" (15).

Nuevamente elegido diputado, por la virtual totalidad de los votos del colegio electoral. de Arequipa, incorporóse al Congreso Constitu-

(13).-Cf. Manning: ob. cit.

(14).-Manuel Lorenzo de Vidaurre: Suplemento a las Cartas Americanas (Lima, 1827). Cf. pp. 275-278.

(15).-Cf. Manning: ob. cit. 
yente, reunido en Junio de 1827, y presidió sus sesiones en dos períados - primero, desde el 4 de junio hasta el 4 de julio de 1827, y luego, desde el 4 de marzo hasta el 4 de abril de 1828-. Decidió la elección del general José de La Mar como Presidente Constitucional, porque su carácter caballeroso y su respeto a la ley parecían destinados a impedir un nuevo brote autoritario; y para ello minó hábilmente la candidatura del general Andrés de Santa Cruz, pues, no obstante sus dotes administrativas y sus recientes demostraciones de liberalismo, no olvidaba que había promovido el motín de Balconcillo y la adopción de la constitución vitalicia. De otra parte, Luna Pizarro confiaba en ejercer su influencia sobre el gobierno, ya a través de la mayoría liberal asegurada en el Congreso Constituyente, ya en las amistosas conversaciones entabladas con el Presidente en el retiro de su gabinete; y la opinión pública, así como la prensa de oposición, atribuyeron entonces los favores y disfavores políticos a la oculta y enconada intervención del presbítero arequipeño, quien hubo de efectuar alguna explicación pública y alegar que no frecuentaba los círculos palaciegos, para eludir su responsabilidad en los aciertos y desaciertos del régimen. En tanto, fué acreditado como Ministro Plenipotenciario (19 de noviembre de 1827) para negociar con el agente diplomático de Chile las bases de un tratado de "alianza, navegación y comercio" (16); solicitó entonces el permiso del Congreso para retirarse de su seno en tanto que desempeñabo esa misión, y evitar así que pudiese sospecharse de su independencio legislativa; pero unánimemente

(16).-La resolución que así lo acredita, inédita y desconocida hasta hoy, se conserva autógrafa en el archivo familiar del doctor Carlos Ortiz de Zevallos Paz-Soldán, a cuya gentileza debemos el poder trascribirla. Dice así:

"El ciudadano José de La Mar, Gran Mariscal de los Ejércitos Nacionales, Presidente de la República Peruana $\& \& \&$

"Por cuanto, el Señor Ministro Plenipotenciario de la República de Chile, ha invitado a este Gobierno a nombre del suyo, para formar bases de alianza, navegación y comercio que determinen y establezcan de un modo sólido y permanente las relaciones que naturalmente existen entre ambos Estados: y debiendo investirse con facultades suficientes un Ministro plenipotenciario que por parte del Perú formalise dichas bases, y mereciendo la confianza del Gobierno el Doctor Don Francisco Javier Luna Pizarro, por reunir las calidades indispensables a tan importante objeto: Por tanto, y en conformidad de la atribución $6^{\mathrm{a}}$ del Poder Ejecutivo, he venido en nombrar Ministro Plenipotenciario con el espresado fín, confiriéndole poder es- 
denegóselo el Congreso, por "consideración a la misma Asamblea" y a las calidades individuales del peticionario; y tal resolución fué, en verdad, bastante previsora, pues el plenipotenciario se limitó a comunicar su designación y proponer al negociador chileno un contraproyecto de tratado $y$, en vista del estancamiento de la gestión, hubo de presentar su renuncia (29 de noviembre de 1828).

En el Congreso favoreció la rehabilitación y la reforma de la Constitución de 1823, y logró que la ley fundamental sancionada en 1828 incluyese sus principales dictados y se limitase a moderar su liberalismo extremoso. Atento a la posibilidad de una reacción bolivarista, consideró necesario preparar la guerra contra Colombia; justificó la invasión de Bolivia y la expulsión del Mariscal de Ayacucho, Antonio José de Sucre, logradas por el general Agustín Gamarra tras una fácil campaña; y propició la anexión de Guayaquil, en vista de los sentimientos peruanistas que alentaban influyentes elementos de esa ciudad. Declarada la guerra entre Perú y Colombia, quiso prevenir la amenaza militarista que alentaba las ambiciones de Gamarra, pero sin aventurar una ruptura; y para consolidar las debilitadas posiciones del gobierno sugirió un acercamiento con los opositores del liberalismo, cuando el vice-presidente Manuel Salazar y Baquíjano -en ejercicio del poder ejecutivo- intentó estructurar un nuevo gabinete; pues, al comprometerse para desempeñar el Ministerio de Gobierno ( 30 de setiembre de 1828); propuso que se incluyera al entusiasta bolivarista José María de Pando como Ministro de Hacienda, y declinó la nominación cuando un mal entendimiento ocasionó la negativar de "éste. Y cuando el presidente La Mar fué depuesto, la odiosidad de sus activos adversarios descargóse sobre Francisco Xavier de Luna Pizarro, quien hubo de sufrir en Lima una vejatoria prisión, por orden del general Antonio Gutiérrez de la Fuente, y salir desterrado a Chile por tercera vez.

Aunque supiera cuán veleidosos son el poder y la fortuna, y antes hubiera saboreado la amargura que deja su frustración, los tratos y la prisión que antecedieron a este nuevo destierro dieron otro giro a sus

\footnotetext{
pecial y las facultades necesarias, para que con arreglo a las instrucciones que recibiere desempeñe esta comisión.

"Dado, firmado y sellado con las armas de la República, y refrendado por el Ministro de Estado y Relaciones Esteriores, en el Palacio del Gobierno en Lima, a diez y nueve de Noviembre, de mil ochocientos veinte y siete $-8^{\circ}$ de la independencia y $6{ }^{\circ}$ de la república. José de la Mar - P. O. de S. E. F. J. Mariátegul".
} 
meditaciones. Su confianza en la libertad, entendida como voluntario y general acatamiento de la ley, había sido severamente mellada. Y quizá recordaría la dura inculpación que un día no lejano le consagrara el Libertador: "Luna engañó a Riva Agüero; Luna echó a Monteagudo y a San Martín; Luna perdió a la Junta Gubernativa; por culpa de Luna entró en el gobierno Riva Agüero, y por culpa dé Luna entró Torre Tagle; por Luna se perdió el Perú enteramente y por Luna se volverá a perder, pues tales son sus intenciones" (17). Quizá repetiría mentalmente la desdeñosa pintura que de su influencia trazó el general Agustín Gamarra, cuando quiso demostrar hasta qué punto habípr sido desconcertada la política del presidente La Mar: "Miles de hombres gimen bajo el peso del despotismo de Luna Pizarro, que se ha hecho el regulador de nuestros destinos, y el patriarca de esas nocturnas sesiones donde se iuzga de todo, se dispone en Jefe, ordena y manda" (18). Quizá llegaría a conocer, en esas oscuras circunstancias, la condenatoria incitación que epistolarmente lanzara el general Andrés de Santa Cruz, al reservar su aplauso a la conducta del general Antonio Gutiérrez de La Fuente, por "no haber fusilado a Luna" (19), y sentenciar: "Si Luna existe todavía en el Perú, no hay que contar con nada bueno, [porque] ese endiablado es incompatible con el bien de la república" (20). Por añadidura, advertiría que ya se aproximaba a la media centuria, sin haber logrado una satisfactoria aplicación de los principios que profesaba, ini haber conquistado una duradera estimación; o que era necesario aceptar y encarar la realidad, sin esforzarse por modelarla. Y aunque difusamente, ¿no pensaría tal vez en quemar lo que había adorado?

Lo cierto es que el tercer destierro modera el liberalismo intransigente del presbítero Francisco Xavier de Luna Pizarro. Y ya se encuentra dispuesto a iniciar en su vida un nuevo curso, cuando inesperada-

(17).-En carta al general Antonio Gutiérrez de La Fuente, suscrita en Magdalena a 6 de abril de 1826.

(18).-En carta al general José de La Mar, suscrita en Piura a 7 de junio de 1829. Cf. su Epistolario (Lima, 1952).

(19).-En carta al deán Manuel José Fernández de Córdoba, suscrita en La Paz a 15 de junio de 1826. Inserta en Los 5 primeros capitulos del manifiesto de Santa Cruz de 24 de octubre de 1840, publicados con notas comprobatorias de las falsedades que contiene (Sucre, Imprenta de Beeche y Ca., 1843). (20).-En carta al general Antonio Gutiérrez de La Fuente, suscrita en La Paz a 22 de junio de 1829. El manuscrito autógrafo se conserva en el Archivo Paz Soldán, existente en la Biblioteca Nacional: vol VI. 
mente lo envuelve el destino en la marejada de las pasiones: porque el general Antonio Gutiérrez de La Fuente, en ejercicio del poder ejecutivo durante la ausencia del presidente Gamarra, lo promueve al deanato del cabildo diocesano de Arequipa ( 8 de marzo de 1831) y no se ve en ello una reparación sino una prueba del acercamiento planeado entre el vicepresidente y los liberales para socavar la estabilidad del régimen. Y como también llegara a su retiro la noticia de la asonada contra el general La Fuente, aguardó que su nombramiento produjera alguna reacción. A la postre se limitó a otorgar su poder a Manuel del Rivero, chantre de aquella iglesia, para que tomase posesión del deanato; y cuando volvió a la blanca ciudad, al iniciarse el año 1832, declaró a sus amigos que deseaba consagrarse a su ministerio. Pero el 20 de marzo fué sorpresivamente acreditado como Ministro Plenipotenciario ante la Santa Sede; y, dada la urgencia que se atribuía a tal misión, cuando el gobierno anunciaba la sangrienta represión de un movimiento conspirativo, se vió en ella un honroso destierro. Encendidamente protestó ante Manuel Lorenzo de Vidaurre, Ministro de Gobierno y Relaciones Exteriores, anotando las violaciones constitucionales que el nombramiento implicaba, y expresando que no aceptaría la legación para no confirmar la.peligrosidad que tácitamente se le imputaba; y protestó también ante el Consejo de Estado, advirtiendo que juzgaba desd'oroso para el país y para sí mismo, exhibir en la Santa Sede una credencial autorizada por un ministró irreligioso, y asumir una misión que en verdad envolvía un castigo injusto; y enfáticamente declaró que estaba "resuelto a primeró suffire la muerte, que Tesignar[s]e a la figurada legación". A los veinte días era revocada la designación; y, aunque insistiera en su alejamiento de los negocios públicos, Francisco Xavier de Luna Pizarro inició con el presidente Gamarra un intercambio epistolar que pronto se apartó de la cortesía y la cautela, para incidir en la explicarción smistosa. Oficialmente, alega padecer un agudo reumatismo, cuyo alivio espera hallar en las salutíferas aguas de Yura, para excusarse de concurrir a la legislatura de 1832, en su calidad de senador por el departamente de Arequipa No obstante, asume la gobernación de la diócesis ( 7 de julio), en tanto que el obispo José Sebastián de Goyeneche y Barreda emprende. una visitáa apostólica; y al año siguiente, ungido por los votos de su provincia natal, y de Tinta, se traslada a Lima para incorporarse a la Convención Nacional que debía reformar la constitución de 1828.

La llegada de Luna Pizarro "se consideró como un gran refuerzo del partido [liberal], en el sentido de darle jefe, unidad y consisten- 
cia" (21). Y, ya fuera para moderar la beligerancia de aquella facción, o para neutralizar la activa oposición de su caudillo más influyente, el ǵobierno eligió al presbítero arequipeño para ocupar el Obispado de Ayacucho (5 de octubre de 1833), que se hallaba vacante desde que su titular -el reverendo Pedro Gutiérrez de $\mathrm{Coz}$ - fuera trasladado a la diócesis de Puerto Rico. Pero la finalidad de tal distinción era muy clara; y, así como lo hiciera en 1826 y 1832, al recibir los nombramientos en virtud de los cuales debió asumir la representación del Perú en México y en Roma, no vaciló en declinar ( 30 de octubre) el honor que se le confería.

De otra parte, los debates de la Convención Nacional transcurrían sin atender a la expresa finalidiad de su convocatoria, porque la Comisión de Constitución no terminaba ningún proyecto, y vióse en ello una maniobra que para desacreditarla efectuaban en su seno los elementos gobiernistas. En consecuencia, aprovecharon-los liberales una renovación de la mesa directiva ( 12 de noviembre) para incorporar al presbítero arequipeño en esa comisión, que empezó a trabajar activamente y dió forma $\alpha$ un proyecto ( 9 de diciembre) que introducía sustanciales innovaciones en la constitución de 1828, al suprimir la prohibición de los pactos federales, admitir la suspensión temporal de las garantías constitucionales, y crear un consejo de estado. Pero el problema que mayores inquietudes ocasionaba era entonces la elección presidencial, pues la renovación del mandato debía efectuarse el 20 de diciembre y, apartel de los conflictos que pudiera originar la falta de un'sucesor legal, nō segsabía a quél disposiciones había de sujetarse el procedimiento eleccionario, y aun se temía las objeciones a la competencia de la misma Convención Nacional. En tal incertidumbre, los liberales eligieron presidente de esta asamblea legislativa a Francisco Xavier de Luna Pizarro eł 12 de diciembre; y éste manejó muy hábilmente sus hilos para asegurar la elección del general Luis José de Orbegoso como Presidente Provisorio, y sortear así la crisis determinada por la sucesión del Mariscal Agustín Gamarra. Pero ya habían amainado sus viejos impulsos, y en aquellos días escribe al general Domingo Nieto: "Si triunfan los liberales el país ganará algo, no mucho; [y] yo perderé mi quietud, porque entonces comenzará a desplegarse el odio encarnizado". No extraña que sus amigos lo hallaran animado por un sorprendente- espíritu de conciliación, y que sin reparo lo atribuyeran

(21).-Santiago Távara: Historia de los partidos (Lima, 1951). Cf. p. 123. 
al temor que le inspiraba la posibilidad de sufrir un cuarto destierro. En efecto, preconizó la federación con Bolivia, como un medio de moderar en cada estado las atribuciones del poder ejecutivo, y sugirió al seneral Andrés de Santa Cruz como su posible realizador; admitió que el Mariscal Agustín Gamarra había hecho posible la alternabilidad en el ejercicio del poder y había demostrado su republicanismo, al concluir su mandato en la fecha estipulada por la ley; y favoreció un entendimiento con el mismo expresidente, para superar los recelos que ensombrecían los comienzos de la nueva administración. Sin embargo, prevalecieron la intransigencia y la desconfianza. El Presidente Provisorio se refugió en las fortalezas del Callao ( 3 de enero de 1834) y, presentándolo como fugitivo, el general Pedro Bermúdez encabezó al día siguiente un pronunciamiento militar. El local donde sesionaba la Convención Nacional fué allanado, pero los diputados se reunieron secretamente y condenaron la subversión del orden legal. Amenazado por una orden de expatriación, Francisco Xavier de Luna Pizarro se adhiere a los diputados del departamento de Arequipa en una valiente protesta, y permanece oculto en Lima. Pero al fin cede la marea. Los facciosos abandonan la capital, acosados por la hostilidad del pueblo; el general Luis José de Orbegoso retorna triunfalmente y prepara una campaña para afianzar el orden legal; la Convención Nacional, que en las fortalezas chalacas reanuda sus tareas, reelige al caudillo liberal como presidentel (12 de febrero) ; y el país queda pacificado cuando las fuerzas en pugna se abrazán en eb campo de Maquinguayo. Renace la confianza en el imperio de la ley, y en la nueva constituclón se afianza la influencia del liberalismo.

Aquella fué la postrera actuación política del presbítero Francisco Xavier de Luna Pizarro. Y claramente se advierte que en ella no aplicó la energía y la elocuencia que antes lo hicieron influyente y odiado; que, en verdad, se dejó llevar por las circunstancias, por la intransigencla principista que sus amigos le vieron desplegar en los anteriores episodios de la lucha mantenida entre autoritarios y liberales. Ya no desaflaba a los poderosos: los temía. Ya no le bastaba la satisfacción de su propia conciencia: quería merecer aun la justificación de sus advertradictorias alternativas que sus auspicios habían provocado: pues, a fin de evitar la derivación hacia el despotismo y salvaguardar la potencla de la soberanía popular, había recortado las atribuciones del poder ejecutivo hasta reducirlo a ser el brazo ejecutor de los designios del 
legislativo; $\mathrm{y}$, tanto en 1823 , como en 1829 y 1834 , la debilidad de los gobiernos cuya formación había inspirado fué, precisamente, la causa primaria de los atentados que las ambiciones despóticas acometieron, en perjuicio de la ley y la soberanía popular. Cierto que su pensamiento político no se tendió nunca hacia una perspectiva lejana, sólo atendió al requerimiento de las circunstancias inmediatas, y favoreció la adopción de medidas cuya estabilidad fiaba a la costumbre y a la virtud civil; pero en esta coyuntura no denota ya clarividencia y deja traslucir su inspiración personalista. Por eso olvida que en 1823, para oponerse a la influencia bolivariana, había concebido el plan de "estrechar nuestras relaciones con Chile, haciendo de ambos pueblos, en cuanto pueda ser, uno mismo"; y no obstante preconizar la federación con Bolivia, en 1834, la cree inconveniente porque "Gamarra la ha propuesto en los mismos términos en que podríamos nosotros haberla indicado". $\mathrm{Su}$ estrecho personalismo ha de proyectarse aún sobre la crisis determinada por el establecimiento de la Confederación Peruano-Boliviana; y aunque sólo asiste a su turbulento desarrollo desde el oscuro recinto donde quiso apaciguar su ánimo, debió meditar con tristeza en las lecciones de su vida. Para labrar su consuelo resolvió, entonces, adorar lo que había quemado.

De manera efímera juega aún su nombre, como miembro del Consejo de Estado que el 3 de junio de 1835 creó el general Felipe Santiago Salaverry, para consultar los graves asuntos del gobierno. En 1836, el general Luis José de Orbegoso gutoriza su nombramiento como deán del cabildo metropolitano; $y$, a solicitud del Arzobispo de Lima, lo designa el Sumo Pontífice para desempeñar algunas funciones auxiliares en esta arquidiócesis, con el título de Obispo de Alalia in partibus infidellum. Es consagrado el 21 de setiembre de 1837 y, retirado desde entonces en el convento de San Francisco, se dedica tan intensamente a las obligaciones de su ministerio, que llega a convertirse en adversario de los liberales con quienes un tiempo compartió la responsabilidad. de la dirección política del país. Vacante el arzobispado en marzo de 1843, Francisco Xavier de Luna Pizarro asumió su administración, en calidad de vicario capitular; $y$, preconizada su designación por el gobierno del general Manuel Ignacio de Vivanco - sobrino político del prelado-, fué aprobada en el consistorio celebrado el 24 de abril de 1845: Se desconocía en Lima este nombramiento, cuando el gobierno presidido por el general Ramón Castilla decidió patrocinar la misma proposición, en julio de 1845; y en atención a este hecho se dió el pase a la respectiva 
bula ( 26 de setiembre), pues la primera presentación no había sido efectuada por una autoridad constitucional. Tomó posesión de la sede el 27 de abril de 1846. Al frente de ella dispuso las exequias tributadas a los restos de los presidentes La Mar y Gamarra, gestionó la condenación papal contra los alegatos regalistas de su amigo Francisco de Paula González Vigil, señaló como erróneas algunas ideas que antes profesara con entusiasmo, cauteló la enseñanza de las doctrinas aprobadas por papas y concilios, y siguó dolidamente los embates que sufría el poder temporal de la Iglesia. Legó su nutrida biblioteca al Seminario de Santo Toribio, y a la Catedral de Arequipa las joyas sagradas que había hecho labrar en París el año 1835. Alegó precedentes y viejas disposiciones para que se le diese sepultura en la Catedral de Lima. Y murió beatíficamente el 9 de febrero de 1855.

\section{BIBLIOGRAFIA ESPECIAL}

ALTMANN SMYTHE, JULIO. Semblanzas del Doctor Francisco Javier de Luna Pizarro, Presidente del Primer Congreso Constituyente del Perú. Callao, Imprenta Colón, 1931.

64 , [1] p. Retrato fuera de texto. $18 \mathrm{~cm}$.

BELAUNDE TERRY, FRANCISCO. Reflexiones sobre el sentido de la actuación de Luna Pizarro en 1827. En Historia: No 8, pp. 327-335; Lima, X-XII de 1944 .

GARGUREVICH, ENRIQUE. Francisco Javier de Luna Pizarro, prócer de la emancipación. gen URevista del Centrol de Estudios Histórico - Militares: No 10, pp. 115-120; Lima, VII-1954 a VIII-1955.

LAVALLE, JOSE ANTONIO DE: Galería de retratos de los arzobispos de Lima (1541-1891). Publicada por don Domingo de Vivero. Lima, Imprenta y Litografía de la "Librería Clásica y Científica", 1892. pp. $39-40$.

LEGUIA, JORGE GUILLERMO. Algo sobre Luna Pizarro, político. En Boletín Bibliográfico: Vol. IV, No 1-2, pp. 2-8; Lima, junio de 1929. En Boletín del Museo Bolivariano: No 12, pp. 432-437; Lima, VIII-1929. $\mathrm{Y}$ en su Historia y Biografía (Santiago de Chile, Editorial Ercilla, 1936).

MARTINEZ, SANTIAGO. La Catedral de Arequipa y sus capitulares. Arequipa, Tipografía Cuadros, 1931. pp. 83-91.

Arequipeños ilustres. Arequipa, Tipografía Cuadros, 1938. pp. 37-52. MENDIBURU, MANUEL DE. Diccionario Histórico-Biográfico del Perú. Tomo V. Lima, Imprenta Bolognesi, 1885. pp. 98-99.

RELACION de los méritos y exercicios literarios del presbitero Llcdo. D. Francisco Xavier de Luna Pizarro, cura de la doctrina de Torata en el Obispado de Arequipa. Sevilla, sin imp., 1809. 4 p. $33 \mathrm{~cm}$. 
RIBEYRO, JUAN ANTONIO. Biografía del Ilmo. Dr. D. Francisco J. Luna Pizarro. En Anales Universitarios del Perú: Tomo IV, pp. 17-43; Lima, 1870.

SCHWAB, FEDERICO. El inventario de la biblioteca de Francisco Xavier de Luna Pizarro. En Fénix: No 7, pp. 146-161; Lima, 1950.

SIVIRICHI, ATILIO. Historia del Senado del Perú. Tomo I: Periodo inicial (1829-1845). [Lima, Talleres Gráficos P. L. Villanueva, S. A., 1955]. Pp. 229-231.

TAUREL, R. M. Colección de Obras Selectas del clero contemporáneo del Perú, con biografía de los autores y varios documentos interesantes sobre el estado actual de la Santa Iglesia del Perú, recogida y ordenada por ... París, Libreria de A. Mázin, 1853. Vol. I, pp. 213-312. Biografía del Iltmo. y Revmo. Sr. D. Francisco de Luna Pizarro, Arzobispo de Lima. En Boletín del Museo Bolivariano: No 8, pp. 263265; Lima, IV-1929.

TAURO, ALBERTO. Cartas inéditas de Luna Pizarro. En Revista Histórica: Tomo XVIII, entrega II, pp. 298-310; Lima, 1950.

Biografía de Francisco Xavier de Luna Pizarro. En El Comercio: Lima, 19 - 1 - 1954.

UGARTE y UGARTE, JOAQUIN. Un interesante retrato histórico de Luna Pizarro. En El Comercio: Lima, 9-II- 1955.

VARELA y ORBEGOSO, LUIS. Los Presidentes de la H. Cámara de Diputados del Perú. Lima, Empresa Tipográfica, 1916. pp. 5-7.

COLMENARES, Manuel Antonio (Lima, 1788-1874), abogado. Suscribió el acta de la independencia y representó a Huancavelica en el primer Congreso Constituyente.

Manuel Antonio Colmenares cirel magistrado cuya prominente naríz excitó la chispeante musa de Felipe Pardo y Aliaga- nació en Liina, el 17 de enero de 1788. Después de hacer sus estudios de primeras letras, ingresó al Seminario Conciliar de Santo Toribio, donde cursó Filosofía, Derecho y Teología, con una contracción tan ejemplar y denotando poseer una memoria tan excepcional que sus maestros le otorgaron las más altas distinciones. El 5 de junio de 1807 le fué conferido el grado de Bachiller en Leyes, en la Universidad Mayor de San Marcos, después de haber expuesto la tesis reglamntaria y de haber replicado satisfactoriamente a los argumentos que le opusieron José Joaquín de Olmedo y Felipe Beltrán. Inició entonces su práctica forense, en el estudio d'el doctor Manuel Antonio Noriega, director de conferencias del Colegio de Abogados; y cuando asistió a éstas, durante los años 1808 y 1809, demostró "las más distinguidas luces, hijas de su mucha aplicación y buen talento". En 1811, cumplidos ya los cuatro años de práctica exigidos por las constituciones universitarias, soli- 
citó que se le examinase para ejercer la profesión de abogado; consecuentemente, rindió las pruebas de jurisprudencia práctica ante la Junta del Colegio de Abogados (8-XI), y en acuerdo de la Real Audiencia informó (14-XII) sobre un pleito que al efecto se le señaló, e hizo el juramento de ley. Pero aun debía culminar sus estudios con el grado de doctor en jurisprudencia, y para optarlo sostuvo en la Universidad Mayor de San Marcos una brillante tesis, el 9 de julio de 1815 (1).

Aunque dedicado al ejercicio profesional, Manuel Antonio Colmenares siguió los vaivenes políticos y miitares del país. Se hallaba vinculado a los círculos patriotas, y debió cooperar intensamente en la preparación de la independencia. Suscribió el acta aprobada por el Cabildo de Lima, bajo la protección de las tropas conducidas por San Martín; tal vez colaboró, con Francisco Javier Mariátegui y José Faustino Sánchez Carrión, en los órganos de prensa que asumieron una actitud nacionalista y republicana; participó activamente en la agitación popular que originó la deposición del ministro Bernardo Monteagudo (25-VII-1822); y, cuando se reunieron en Lima, los colegios electorales (29-VII) lo acreditaron para integrar el primer Congreso Constituyente como diputado por Huancavelica, en atención a su "conocida aptitud para el alto cargo" (2). Prestó juramento al instalarse la magna asamblea; y fué designado para integrar las comisiones de Bellas Artes, Instrucción y Salud Pública, y de Premios y Agricultura. En armonía con una disposición del propio Congreso, declaró (12-IV-1823) a la comisión de dietas no tener. "sueldo ni renta alguna", pues aun las eventuales ganăncias de daiprofésión de abogado le habián quedado vedadas en cuanto aquel prohibió a sus miembros suscribir recursos e informar en la Alta Cámara de Justicia. Consagróse, pues, a ejercer la representación que le había sido confiada; y durante los debates preparatorios de la Constitución asumió la posición liberal, defendiendo la tolerancia de cultos, el sufragio popular y la libertad de imprenta. A la elocuencia y la versación de sus intervenciones debió el ser uno de los más influyentes tribunos de esta histórica asamblea, cuyos miembros le confiaron la secretaría en dos períodos (IX-1823 y 1-1824).

(1). - El expediente seguido para optar grado de conserva en el archivo de la antigua Audiencia de Lima, bajo la actual custodia de la Corte Suprema de Justicia.

(2).- Cf. la respectiva acta del colegio electoral, asi como los documentos pertinentes a su gestión parlamentaria, en el archivo de la Cámara de Diputados. 
Cuando las fuerzas realistas ocuparon Lima, las principales entidades del gobierno hubieron de refugiarse en las fortalezas del Callao; y, para evitar que sus deliberaciones estuviesen sometidas a la presión de las bayonetas, Manuel Antonio Colmenares y otros diputados resolvieron seguir al Presidente José de la Riva Agüero hasta Trujillo. Con tal fín, la tesorería del Cengreso le abonó la cantidad de 98 pesos 7 reales, a cuenta de sus dietas (16-VI-1823). Pero en aquella ciudad contrarió Riva Agüero los principios de la política representativa, al pedir a los diputados que formasen un Senado de 10 miembros y luego declarasen disuelto el Congreso; provocó así una lógica negativa de cuantos advirtieron que tal incitación desconocía anteriores acuerdos del propio Congreso y revelaba una tendencia autocrática; y, exacerbado su ánimo por la insegura posición de su gobierno, tomó ingratas represalias. Con otros representantes del pueblo, Manuel Antonio Colmenares fué puesto en prisión; y antes de que alborease el nuevo día fueron todos conducidos a Huanchaco y embarcados en una goleta llamada Veloz Trujillana, cuyo capitán debía conducirlos hasta Arica, para entregarlos a la custodia del General Andrés de Santa Cruz. Pero la nave debió hacer escala en Chancay (12-VIII), para aprovisionarse de agua, y la población exigió la liberación de los prisioneros. Sin reparo accedió a ello el capitán, y los diputados fueron acogidos en el puerto con repiques de campanas, misa jubilar y otros festejos. Al día siguiente emprendieron marcha hacia Lima, escoltados por un grupo de agricultores. Un canonazo anunciósú llegaida a la ciudad; y las comisiones que acudieron airecibirles, engrosadas por numerosos elementos populares, desfilaron tras ellos entre salvas de cohetes y atronadores repiques, primero hasta la casa del Presidente del Congreso - doctor Justo Figuerola- y. luego a la Municipalidad.

En Trujillo, Riva Agüero mantuvo su actitud disidente, y el Congreso autorizó a Bolívar para reducirlo por la fuerza. Luego adoptó di-versas resoluciones para favorecer los aprestos militares. Y finalmente dispuso el receso de sus propias funciones y confió al Libertador la diciadura (10-11-1824), cuando se produjo la defección de las guarniciones que defendían las fortalezas chalacas. Pero aun volvió a reunirse un año más tarde, para expresar a Bolívar la gratitud que el país le debía por el definitivo afianzamiento de su independencia y prorrogar la dictadura. Entonces dispuso el gobierno que se efectuase un ajuste de las dietas debidas a los diputados, y a Manuel Antonio Colmenares tocóle un alcance de 4951 pesos 1 real. $Y$ por los eminentes servicios 
que en el seno del Congreso había prestado a la república, le fué otorgada poco después la medalla cívica con el busto del Libertador.

En adelante consagróse al ejercicio de la abogacía y a la magistratura, desde las cuales quiso contribuír a la estabilidad institucional, que a su parecer requería la neutralización de las pasiones mediante una honesta aplicación de la ley. Distinguióse por los esfuerzos que cplicó a la represión de los excesos en que incurría la prensa, con daño para el orden público y el honor de las personas: primero como juez de hecho (VI-1825), y luego como agente fiscal (30-1-1830). Integró el Tribunal de los Siete Jueces, instalado (27-IX-1831) para "conocer las causas de responsabilidad que se entablen contra la Corte Suprema por los abusos del poder en el ejercicio de sus oficios y que no induzcan criminalidad". A poco fué designado para desempeñar las funciones de fiscal de la Corte Superior de Lima, cargo al cual se hallaban anexas las de fiscal de la Junta de Liquidación y de la Junta de Beneficencia. En uso de sus atribuciones formuló denuncia contra las tendencias sediciosas de El Limeño (1l-VIII-1834) - "que sin embargo de su ningún mérito likerario para los inteligentes, contiene mentiras estudiosamente inventadas y excesos gratuitamente atribuídos a la Convención y al Ejecutivo"- y así excitó la vena satírica de Felipe Pardo y Aliaga, quien pertenecía a los círculos de la oposición al gobierno y trazó la caricatura del fiscal en notables letrillas y sonetos.

A sus deberes como fiscal de la Corte Superior de Lima se agregaron, en 1838, los concernientes a la censura teatral. Y, si bien es cierto que sus opiniones fueron severamente inspiradas por una moral dogmática y una disciplina Clásica, en̉o debevolvidarse que supo prestar "su apoyo a todas las jóvenes inteligencias que se iniciaban en la literatura dramática" (3); pues, así como "nunca citó una ley sin conocer su índole, su generación, sus vicisitudes, su influencia y su predominio sobre las costumbres que corregía, y las ventajas que resultaban de su aplicación y cumplimiento estrictos" (4), así vertió en sus críticas de teatro muy precisas observaciones sobre el estilo y sobre las proyecciones éticas de la intriga. Veía en la escena un medio de orientar al pueblo en la estimación de las virtudes cívicas e individuales, y creía coadyuvar a tal finalidad desde su cargo en la Junta Cen-

(3).- Félix Cipriano Coronel Zegarra, en Diccionario Biográfico Americano compilado por José Domingo Cortés (Lima, 1875).

(4).- Juan Antonio Ribeyro, en la semblanza biográfica de Manuel Antonio Colmenares, incluida en su Galeria Universitaria. Cf. Anales Universitarios del Perú: Tomo XIII, pp. 5-57; Lima, 1876. 
sora; pero renunció a integrarla (3-VII-1855) cuando los cambios sociales determinaron su ruptura con las nuevas formas de la sensibilidad. Interinamente promovido para ocupar una vocalía en la Corte Suprema de Justicia (29-VIII-1841), Manuel Antonio Colmenares se pronunció contra la validez del contrato que el gobierno había suscrito (29-XII-1840) con Francisco Quirós y Aquiles Allier, y por el cual se había reconocido a éstos el privilegio para exportar guano, durante un período de seis años y abonando al estado sólo una mínima suma de 60,000 pesos. Así determinó la formulación de un nuevo contrato (8YII-1841), que proveía a la justa defensa de los intereses nacionales mediante la participación proporcional del estado en las utilidades líquidas de la exportación. Y es evidente que se dió a este hecho su justa significación, pues, al iniciarse la fecunda administración del general Ramón Castilla, algún sector de la opinión sugirió (5) la conveniencia de que el honesto magistrado ocupase el Ministerio de Guerra, para dar principio a "la nueva y regeneradora era del Perú".

Por breve tiempo ejerció la docencia en el Convictorio de San Carlos, cuando Bartolomé Herrera inició la reforma de los estudios profesionales; fué juez de alzada del Tribunal del Consulado (1848-1850); y, finalmente, vocal del Tribunal de Apelaciones. Retiróse de la magistratura hacia 1860 Y murió el 12 de mayo de 1874.

\section{Biblioteca de Letras}

TEJEDA, José Simeón (1826 - 1873), abogado y político. Representó a su provincia natal en la Convención Nacional de 1855. Integró la comisión encargada de redactar los proyectos de Código Penal y de Enjuiciamientos en Materia Penal. Fué Ministro de Justicia e Instrucción en el gobierno dictatorial del coronel Mariano Ignacio Prado. Y, elegido nuevamente diputado, en 1872, presidió las sesiones de su Cámara.

José Simeón Tejeda nació en el pueblo minero de Andaray -perteneciente a la provincia de Condesuyos, del departamento de Arequipa- y puede creerse que su estampa lo impresionó en forma definitiva, porque su medio millar de habitantes vivía a costa de la explptación aurífera, sólo mediante el comercio con las poblaciones vecinas obtenía los suministros que la pobreza de la tierra no brindaba, y apenas se conmovía ante los frecuentes cambios de la política nacional. Ofre-

(5).- En El Comercio: Lima, 19-VI-1845. 
cía un leve ejemplo de la influencia que el trabajo puede tener sobre los pueblos, cuando se aplica a la industria y el comercio, en un ambiente de paz. Y tanto en sus trabajos escritos, como en sus gestiones parlamentarias y administrativas, José Simeón Tejeda se esforzó por dar relieve a tales factores de progreso.

Hizo sus estudios en el Colegio de la Independencia y en la Universidad del Gran Padre San Agustín, de Arequipa. El 8 de agosto de 1851 obtuvo el título de abogado, profesión que comenzó a ejercer "con esperanza bien o mal fundada". Al año siguiente fué elegido miembro de la Academia Lauretana de Ciencias y Artes y durante la ceremonia a que dió lugar su incorporación ( 6 de agosto de 1852) pronunció un. celebrado discurso, en torno a la Emancipación de la industria (Arequipa, 1852; y Lima, 1947), en el cual justificó la Inecesidad de evitar la influencia política sobre el trabajo productivo, y estableció los estímulos que el progreso nacional podría hallar en el libre desenvolvimiento de la iniciativa personal. Por acuerdo de la misma Academia debió ejercer las funciones de maestro en las disertaciones de Derecho Público, que ante ella solían sustentar los alumnos de la Universidad de Arequipa; y, con José Domingo Rosel y José María Químper, integró (28 de febrero de 1853) la comisión que, a solicitud del Prefecto José de Rivero, debía informar sobre el estado de las escuelas primarias de aquella ciudad. De otra parte, contribuía a la redacción de El Republicano, semanario oficial en cuyas páginas se halla fielmente reflejadas las alternativas políticas e ideológicas de aquellos años. Y desde sus columnas dió resonañoiagal Pmovimientö Gevolücionario que inició en Arequipa el general Ramón Castilla, con el auxilio de los liberales, para derrocar al gobierno conservador del general José Rufino Echenique.

Llevado por la marea de la revolución, José Simeón Tejeda secundó a Pedro Gálvez en la secretaría general.. Luego fué designado auditor de guerra, y como tal hubo de asesorar a los jueces militares en las numerosas causas incoadas para mantener la disciplina. Ingresó a Lima con las fuerzas revolucionarias. Y, favorecido por los votos de su provincia nativa, incorporóse a la Convención Nacional, reunida el 14 de julio de 1855 para atender a la crisis económica y social determinada por la supresión de la esclavitud y la abolición del tributo indígena y dar al país una coherente organización legal. El lo de setiembre de aquel mismo año fué elegido en dicha asamblea secretario suplente, reelegido el $1^{\circ}$ de octubre, y promovido a la secretaría el $1^{\circ}$ de noviembre. Sus personales dotes y su versación debieron ser luego ejercitadas en dos comisiones difíciles : la primera ( 4 de diciembre de 
1855), designada para estudiar los actos de la administración del general José Rufino Echenique a la luz de las informaciones contenidas en sus mensajes y las memorias de sus ministros; y la segunda (9 de mayo de 1956), especialmente encargada de dictaminar sobre la legalidad y la conveniencia del contrato pertinente a la consignación de guano en Estados Unidos. En ambas adoptó una posición equilibrada, auspiciando una actitud conciliadora en lo político y la defensa de los intereses nacionales en lo económico, pues juzgaba que la ley debía proteger por igual a todos los ciudadanos y orientar la acción administrativa del estado. Creció por ello su autoridad, y en tres períodos diversos - noviembre y diciembre de 1956, y abril de 1957- fué elevado a la vicepresidencia de la Convención Nacional.

Los más fogosos tribunos de la época debatieron en esa histórica asamblea los fundamentos doctrinarios y las estipulaciones de la Constitución más liberal que haya sido aprobada en el Perú. Y José Simeón Tejeda elevó en su seno la voz de la serenidad, para sosegar las retóricas tempestades en que adquiría expresión el antagonismo entre conservadones y liberales, y asumió así la representación de una tendencia equidistante entre la intolerancia y el arrebato pasional. Sus intervenciones tuvieron con frecuencia un carácter docente; fueron claras y elocuentes, siempre mesuradas y a veces irónicas; y se inspiraron en la necesidad de imponer el respeto a la ley, como expresión de la voluntad popular. De allí su ascendiente en el curso del debate constitucional. Ya, cuando abogó en favor de la supresión de los fueros militar y eclesiástico, por envolversecenlellos un privilegio que contrariaba la igualdad legal de los ciudadanos, por la maliciosa alegación de inmunidad que en ellos se amparaba, y por el menoscabo que así sufría la severa aplicación de la ley. Ya, cuando se opuso a la pena de muerte, advirtiendo que su aplicación impedía la reforma del delincuente y desconocía la inviolabilidad de la persona. Ya, cuando alegó argumentos jurídicos e históricos para desacreditar el proyectado reconocimiento del derecho de insurrección popular, en el cual veía asomar la rebeldía contra la ley y, por ende, el principio de un desórden anárquico. Y con entereza semejante propuso a la Convención Nacional que en sus deliberaciones otorgase prioridad a las infracciones de la Constitución; ante las solicitudes que la ciudadanía elevaba a las autoridades para ocupar empleos en la administración del estado, sostuvo la conveniencia de proveerlos según el mérito, pero denostando contra la rutina al apuntar que el mérito no acompaña siempre a la edad avanzada; y frente a las pretenciones individuales, que tanto proliferan 
Y se acrecientan durante los cambios revolucionarios, invocó la necesidad de evitar las coacciones que pudieran privar de estabilidad y validez permanente a las garantías del estado.

Pero la Convención Nacional prolongó sus trabajos aún después de haber promulgado la constitución; y, habiéndose producido en Arequipa la revolución accudillada por el general Manuel Ignacio de Vivanco, se ocupó en el estudio de otras leyes para mantener su vigilancia sobre la conducta del poder ejecutivo. Hasta que el 2 de noviembre de 1857 fueron interrumpidos los diputados en plena sesión, y hubieron de evacuar el local bajo la amenaza de las bayonetas. Desconcertados por la violencia, nombraron una comisión para que esclareciese debidamente el origen del atentado y propusiese al gobierno las medidas que su castigo exigiera, y en ella incluyeron a José Gálvez, Juan Gualberto Valdivia y José Simeón Tejeda. Pero el hecho estaba ya consumado. $Y$ el tribuno se consagró desde entonces al ejercicio de la abogacía.

Había sido nombrado (6 de setiembre de 1856) para integrar la comisión que debía revisar el proyecto de Código Penal elaborado durante el gobierno del general José Rufino Echenique, y redactar además un proyecto de Código de Enjuiciamientos en Materia Penal; y, bajo la presidencia de Santiago Távara, trabajó en ella con José Gálvez, Ignacio Novoa y.Tomás Lama, hasta dejar terminados los proyectos que, después de sufrir ung revisión dilatoria, fueron solemnemente promulgados el $1^{\circ}$ de marzo de 1863 . Pero, leal a su conciencia política, actuó al mismo tiempo "en la Unión Ânericana, fundada en Lima el año 1857 para promover la solidaridad con las reformas anunciadas por los liberales mexicanos en el plan de Ayutla (1855) y refrendadas luego en la constitución; y que, al producirse la invasión francesa en México, asumió la tarea de movilizar la opinión contra aquella empresa y acopiar recursos para auxiliar a los patriotas que en su país la combation. Desde 1858 colaboró en la Gaceta Judicial, que tan empeñosamente alentó el proteico Manuel Atanasio Fuentes. Y el 17 de mayo de 1861 se incano, el año 1864. Una grave crisis amenazaba entonces al país, debido a las vaci-
laciones que afectaba el gobierno ante la ocupación de las islas de Chincha por la escuadra española del Pacífico, y las exigentes reclamaciones formuladas con el pretexto de perjuicios y malos tratos inferidos a los colonos españoles en haciendas de la costa. En cambio, el Congreso y la prensa reclamaban la ruptura con los agresores. Y pa- 
ra calmar estos 'embates, el Presidente - general Juan Antonio Pezetencargó la reorganización de su gabinete a Manuel Costas, quien solicitó la colaboración de José Simeón Tejeda en el Ministerio de Justicia e Instrucción. El conflicto con España fué encarado con prudencia y firmeza, pero se hizo a veces notoria la discrepancia entre el Presidente y sus ministros. Despedidos éstos al cabo de dos meses, la orientación de la política nacional fué confiada a elementos conservadores, y para negociar con el plenipotenciario español se acreditó al displicente y escéptico general Manuel Ignacio de Vivanco. Llégose así a un acuerdo, cuyos términos parecieron una capitulación ante las exigencias de los agresores, y el descontento se extendió rápidamente. El coronel Mariano Ignacio Prado inició, en Arequipa, la revolución que ya se preveía; tras una fácil campaña, entronizó la dictadura (28 de noviembre de 1865); y rodeado por hombres jóvenes y prestigiosos, entre los cuales figuró José Simeón Tejeda como Secretario de Justicia e Instrucción, asumió el cumplimiento de su histórica tarea desconociendo el humillante tratado, declarando la guerra a España, y excitando el fervor nacionalista.

No solamente en el despacho de los asuntos confiados a su competencia hallaron aplicación la lucidez y la versación del jurista, pues mantuvo una estrecha cooperación con el Secretario de Relaciones Exteriores, doctor José Toribio Pacheco, durante las activas negociaciones que forjaron la "cuádruple alianza" enderezada contra las irreflexivas pretenciones de España, y aún parece que muchas de las comunicaciones circuladas con tal motivose debieron g su equilibrada pluma. El 2 de mayo de 1866 asistió al combate del Callao, con el Dictador y los demás secretarios de estado. Pero en ese heroico episodio culminó la misión del histórico gabinete, y sus miembros decidieron renunciar cuando la Asamblea Constituyente puso término a la dictadura y designó Presidente Provisorio al coronel Mariano Ignacio Prado (17 de febrero de 1867).

Intensa y renovadora fué la obra cumplida por José Simeón Tejeda en la Secretaría de Justicia e Instrucción. De una parte, creó el ministerio fiscal, fijó las normas tendentes a la aplicación de la ley de responsabilidad de los funcionarios públicos, y esclareció numerosos detalles de procedimiento y jurisdicción; y, de otra, adoptó medidas para modernizar la total organización de la enseñanza. "Memorable" fué su actividad en este ramo - según lo establece Jorge Basadre en su Historia de la República-. "El decreto de 15 de marzo de 1866 dispuso que el Convictorio de San Carlos fuera destinado exclusivamente a la enseñanza de las facultades de Derechu, Ciencias y Letras; que ella tu- 
viera carácter universitario, y por consiguiente, dentro de un régimen de externado; y que cada una de las facultades sería dirigida por un Decano nombrado por el gobiemo. Otro decreto del siguiente día fijó el plan de estudios de cada una de las tres facultades, omitiéndose toda asignatura que no fuese estriçtamente universitaria. Así quedó, pues, en forma efectiva, abolida la instrucción media en San Carlos; y así quedaron planificadas las facultades de Letras y de Ciencias. Pensó Tejeda que en el futuro San Carlos estaría integrado por institutos superiores de Dibujo, Pintura y Música. El Jardín Botánico fué creado como dependencia de la Facultad de Medicina, cuya organización era satisfactoria y no recibió, por lo tanto, alteración notable. La Reforma Universitaria fué extendida, en principio, a las provincias, dentro del mismo sistema de facultades, autorizándose o no el establecimiento de cada una de ellas, según las condiciones de cada caso.

"En los colegios procuró Tejeda la uniformidad de los estudios, la finalidad práctica y no pre-universitaria de ellos; la orientación comercial e industrial al lado de la científica y literaria, la supervigilancia sobre los planteles particulares mediante comisiones oficialmente autorizadas. La Dirección General de Estudios fué suprimida y confiada a las comisiones provinciales la disciplina y vigilancia sobre maestros y escuelas. Con el fín de formar profesores, se dió el carácter de escuelas modelo, o sea de pequeñas escuelas normales, a las superiores de cada departamento. Ia Escuela Normal de Lima quedó reorganizada, con el fín de incrementar las rentas, se dispuso que las fundaciones de piedad, beneficencia $y$ otras que no correspondieran a sus fines, formasen parte de los fondos de intsrucción primaria, y que un impuesto de las Municipalidades tendría el mismo objeto. La instrucción de la mujer fué contemplada por el decreto de 27 de junio de 1866; y se permitió el ingreso de mujeres al magisterio elemental".

José Simeón Tejeda retornó a su bufete. Pero nuevamente fué reclamado por la actividad pública; $y$, en cumplimiento de misiones oficiales, o comprometido a respaldar con su autoridad algún movimiento de opinión, no conoció ya el reposo. En 1869 integrió la Junta de Notables de Lima, como Inspector de Instrucción Primaria, y así tuvo oportunidad de orientar la aplicación del impuesto que para el fomento de la enseñanza primaria estableció bajo la dictadura. En forma concomitante, el $1^{\circ}$ de mayo fué nombrado vocal del Consejo Superior de Instrucción, que presidió Manuel Bartolomé Ferreyros en su calidad de Director de Instrucción Pública, que además integraron Juan Oviedo y Miguel de los Ríos, y en cuyo seno se le confió el estudio y la vigilancia 
de la instrucción primaria. Requerido por los universitarios, compartió con Pedro Gálvez la presidencia del mítin que el 30 de mayo se efectuó en el Teatro Principal, con el objeto de expresar la simpatía que la juventud profesaba a la causa de la libertad de Cuba, especialmente realzada en esa ocasión por la asistencia de Ambrosio Valiente, delegado del gobierno revolucionario. En Octubre fué designado para defender los intereses del país en la Comisión Mixta Peruano-Norteamericana, que debía estudiar las reclamaciones formuladas por los ciudadanos de Estados Unidos cuyas propiedades habían sufrido perjuicios durante las guerras civiles. Y los jóvenes escritores, que en 1866 habían constituído la Sociedad Amigos de las Letras para comunicarse los tempranos frutos de su afecto por el estudio y la literatura, apelaron a José Simeón Tejeda cuando-quisieron dar expansión a sus trabajos y ceñirlos a pautas académicas; le confiaron la presidencia del surgente Club Literario, "por la lucidez de su inteligencia, por su ilustración profunda, por la austeridad de su vida, por su civismo ejemplar" - según refirió más tarde Ricardo Heredia-; y fué un obrero tan activo en la labor de reorganización, que ejerció el cargo hasta su muerte.

Diversos hechos anunciaban la proximidad de una nueva crisis política, y José Simeón Tejeda volcó en ella su influencia moderadora. Concurrió el 24 de abril de 1871 a la asamblea en la cual fué proclamada la candidatura presidencial de Manuel Pardo, y, por tanto, coadyuvó a la fundación del Partido Civil. Nuevamente elegido diputado por su provincia natal, en 9872, alentó la protesta del Congreso contra la militarada de los hermanos Gutiérrez, on contribuyó a restablecer la confianza en los fueros de la ley y la voluntad popular. Favorecido entonces por una abrumadora mayoría, presidió la Cámara de Diputados en las legislaturas ordinaria y extraordinaria; y al terminar sus sesiones integró la Comisión Permanente del Congreso. Elegido Alcalde de Lima, en 1873, aplicó sus más persistentes esfuerzos al desarrollo de las escuelas primarias. Y ya era señalado como un digno sucesor de Manuel Pardo cuando murió, el 23 de agosto de aquel año.

Aunque amaba las suscitaciones del arte y la literatura, netamente se percibe que José Simeón Tejeda aplicó su devoción a tres materias fundamentales : la economía, el derecho y la educación. Y siempre que las amparase el ejercicio de la libertad, consideró aquellas tres materias como estímulos del progreso. En la primera identificaba un fín útil, en cuanto su desarrollo tiende a satisfacer las necesidades generales del hombre; y prefería llamarla "industria" para englobar todas las formas de la producción y el trabajo, sugiriendo al mismo tiempo la 
potencia creadora que la anima. Las instituciones del derecho, normativas de los intereses individuales.y sociales, debían fijar las garantías indispensables para que la libertad no quedase reducida a una simple opción entre cometer $u$ omitir un acto $y$, en cambio, amparase a cada individuo en el seguimiento de la actividad o el camino honestamente escogido. En armonía con las ideas de los filósofos del siglo XVIII, estimaba la educación como instrumento propicio a la iniciativa y la eficiencia profesionales, y conveniente al reconocimiento y la defensa de los derechos y los intereses que la ley ampara. De allí la unidad que en sus tres fases presenta el pensamiento de José Simeón. Tejeda, y la coherencia existente entre ellas y su actitud civil.

En las memorias que húbo de redactar sobre el cumplimiento de las obligaciones inherentes a determinados cargos y comisiones, en sus discursos parlamentarios, en artículos periodísticos y disertaciones académicas, se esforzó por incorporar a la vida peruana las orientaciones doctrinarias de su tiempo. Toda su obra tiene, por eso, un alto valor documental. Envuelve la crítica a la realidad, y la visión de un horizonte alcanzable. Se halla ilustrada por un juicio penetrante y severo, que, merced al dominio de la práctica y la teoría coetáneas, ignora los convencionalismos de la intolerancia.

"Desde que estuvo en peligro su vida, y tanto como ha durado ese peligro, tanto como ha durado esa agonía, hemos estado todos también pendientes entre la vida y la muerte como si a éste que es hoy un cadáver hubiese estado vinculada una esperanza general -dijo Cesáreo Chacaltanda cante sul tumball interprétando" el sentimiento de la Honorable Comisión Permanente del Congreso-. Y en verdad que esa esperanza es el secreto del dolor universal, porque don José Simeón Tejeda no fué simplemente un ciudadano honrado, un. hábil jurisconsulto, un orador elocuente, un estadista distinguido. Tejeda fué algo más que eso: Tejeda fué un gran carácter, aquí donde fluctúan tanto los caracteres, como en todas las sociedades que se forman a impulso de las pasiones y de los hechos". Su constancia en la actitud y su firmeza de convicciones lo hicieron prudente y mesurado: "No era ... el magistrado ardiente que de una plumada se promete derribar un edificio de abusos, pero era la abeja trabajadora que fabricaba un buen panal día a día" (cf. El Nacional : Lima, 25-VIII-1873). Y alguien pudo anotar que había cumplido una "vida irreprochable". 


\section{BIBLIOGRAFIA ESPECIAL}

AROSEMENA GARLAND, GERALDO. Apuntes sobre el Colegio de Abogados. Lima, Talleres de la Empresa Periodística, S. A.-, 1947. Cf. pp. $123-124$.

MARTINEZ, SANTIAGO. Arequipeños ilustres. Arequipa, Tipografía Cuadros, 1938. Cf. pp. $213-216$.

RAMIREZ, ZENON. José Simeón Tejada. En Revista Americana: No 12, p. 185; Lima, 30 III - 1892.

SAN CRISTOVAL, EVARISTO. Un varón representativo: José Simeón Tejada. En El Comercio: Lima, 19 - I - 1942.

SENOR DOCTOR DON JOSE SIMEON TEJEDA. En El Perú Ilustrado: No 38, pp. 2-3; Lima, 28-I-1888.

VARELA Y ORBEGOSO, LUIS. Los presidentes de la $H$. Cámara de Diputados del Perú. Lima, Empresa Tipográfica, 1916. Cf. pp. 143-144. 